\title{
Aplikasi biochar sekam padi dan tepung cangkang kerang ale-ale untuk memperbaiki sifat kimia tanah sulfat masam
}

\section{Application of rice husk biochar and shellfish flour to improve the chemical properties of acid sulfate soils}

\author{
Beny Setiawan $^{1 *}$, Khairil ${ }^{1}$, Sarwendah Ratnawati Hermanto ${ }^{1}$ \\ ${ }^{1}$ Program Studi Budidaya Tanaman Perkebunan Politeknik Negeri Ketapang \\ *Email korespondensi: beny.setiawan@politap.ac.id
}

Diterima: 18 September 2020 / Disetujui: 24 Maret 2021

\begin{abstract}
The use of acid sulphate land for soybean cultivation has several problems such as low soil pH and available phosphate. The effort to overcome acid sulphate land margins is by adding biochar and calcification. The study was conducted using a Completely Randomized Design (CRD) consisting of two factors. The first factor is the dose of rice husk biochar with three levels of doses (0,5\% and 10\%) and the second factor is the dose of shellfish flour with three dosages (0, 12, $14 \mathrm{~g} / \mathrm{polybag}$ and 24,28 g/polybag). The parameters observed were the changes in some of the chemical properties of acid sulphate soils. The results showed that the application of rice husk biochar with a dose of $1200 \mathrm{~g} /$ polybag and shellfish flour at a dose of $24.28 \mathrm{~g} / \mathrm{polybag}$ could increase the $\mathrm{pH}$ of acid sulphate soils from 4.28 to 5.83.
\end{abstract}

Keywords: biochar, Shellfish, acid sulphate soil.

\section{ABSTRAK}

Penggunaan lahan sulfat masam untuk budidaya kedelai memiliki beberapa permasalahan seperti rendahnya pH tanah dan fosfat tersedia. Upaya untuk mengatasi kemarginalan lahan sulfat masam adalah dengan penambahan biochar dan pengapuran. Penelitian dilaksanakan menggunakan Rancangan Acak Lengkap (RAL) yang terdiri dari dua faktor. Faktor pertama yaitu dosis biochar sekam padi dengan tiga taraf dosis (0, $5 \%$ dan $10 \%)$ dan faktor kedua yaitu dosis tepung cangkang kerang dengan tiga taraf dosis (0, 12,14 g/polybag dan 24,28 g/polybag). Parameter yang diamati yaitu perubahan beberapa sifat kimia tanah sulfat masam. Hasil penelitian menunjukkan bahwa aplikasi biochar sekam padi dosis 1200 g/polybag dan tepung cangkang kerang dosis 24,28 g/polybag dapat meningkatkan pH tanah sulfat masam dari 4,28 menjadi 5,83.

Kata kunci: biochar, cangkang kerang, tanah sulfat masam.

\section{PENDAHULUAN}

Penggunaan lahan sulfat masam untuk budidaya tanaman memiliki beberapa kendala yang harus dihadapi. Pengembagan pertanian di tanah sulfat masam sering menghadapi beberapa permasalahan seperti rendahnya $\mathrm{pH}$ tanah dan fosfat tersedia serta tingginya kandungan $\mathrm{Fe}$ (Purnomo et al., 2005).

Upaya untuk memperbaiki sifat kimia tanah sulfat masam agar layak digunakan sebagai lahan pertanian diantaranya dengan penambahan biochar dan pengapuran.

Penambahan biochar dapat meningkatkan beberapa sifat kimia tanah seperti $\mathrm{pH}$, KTK, dan beberapa senyawa seperti C-organik, N-total, serta dapat mereduksi aktivitas senyawa Fe dan Al yang berdampak terhadap peningkatan $\mathrm{P}$ tersedia (Sudjana, 2014).

Bahan dasar untuk membuat biochar dapat memanfaatkan sekam padi yang ketersediaannya cukup banyak saat musim panen. Sekam padi berpotensi untuk diolah lebih lanjut menjadi biochar yang dapat diaplikasikan sebagai pembenah tanah.
Pemberian kapur pada tanah dapat meningkatkan $\mathrm{pH}$ tanah dan efisiensi pemupukan $\mathrm{P}$, bahkan mengekstrak $\mathrm{P}$ tanah yang terikat oleh Al atau Fe (Priatmadi dan Haris 2009). Untuk meningkatkan manfaat sumber daya kerang ale-ale secara optimal dengan memperhatikan aspek jangka panjang adalah dengan mengolah limbah tersebut menjadi tepung cangkang sebagai alternatif pengganti kapur pertanian komersil yang ketersediaannya semakin terbatas. Hasil penelitian Mijan et al. (2015) menunjukkan komposisi kimia yang terkandung dalam cangkang kerang ale-ale terdiri dari $98.81 \% \mathrm{Ca}, 0.51 \% \mathrm{Sr}, 0.63 \% \mathrm{~S}, 0.03 \% \mathrm{Cu}$, dan $0.02 \% \mathrm{Br}$. Dengan kandungan kalsium yang tinggi Cangkang kerang memiliki potensi sebagai sumber garam mineral yang berperan penting dalam proses peningkatan $\mathrm{pH}$ tanah sulfat masam.

Adanya potensi sekam padi dan cangkang kerang yang dapat dimanfaatkan sebagai sumber bahan organik dan sumber mineral yang dapat digunakan untuk meningkatkan produktivitas tanah sulfat masam maka perlu dipelajari peranan arang sekam padi dan tepung cangkang kerang aleale terhadap perbaikan sifat kimia tanah sulfat masam. 


\section{BAHAN DAN METODE}

Penelitian ini dilaksanakan di DEM Area Pertanian Percontohan Terpadu Desa Sungai Awan Kanan, Kecamatan Muara Pawan, Kabupaten Ketapang, Kalimantan Barat yang dilaksanakan selama 2 (dua) bulan yang dimulai dari bulan Agustus 2020 sampai dengan bulan Oktober 2020.

Alat yang digunakan dalam percobaan ini adalah : cangkul, sabit, parang, meteran, neraca, ayakan alat tulis kantor dan alat pendukung lainnya. Bahan-bahan yang digunakan adalah Polybag ukuran $35 \mathrm{~cm} \mathrm{x} 40 \mathrm{~cm}$, Terpal, Biochar Sekam Padi dan Cangkang Kerang ale-ale.

Penelitian dilaksanakan menggunakan Rancangan Acak Lengkap (RAL) faktorial yang terdiri dari dua faktor, faktor pertama adalah dosis biochar sekam padi (S) dengan tiga taraf perlakuan yaitu $0,5 \%$ dan $10 \%$. Faktor kedua adalah dosis tepung cangkang kerang ale-ale (K) dengan tiga taraf perlakuan yaitu $0,12,14 \mathrm{~g} /$ polybag dan 24,28 g/polybag. Banyaknya perlakuan dalam percobaan ini ada 9 kombinasi, setiap perlakuan diulang sebanyak 3 kali ulangan dan setiap ulangan terdiri dari tiga sampel sehingga jumlah seluruh sampel sebanyak 81 sampel .

Pengamatan dilakukan terhadap sifat kimia tanah yaitu $\mathrm{pH}, \mathrm{C}$ organik dengan metode Walkley\&Black, $\mathrm{P}_{2} \mathrm{O}_{5}$ dengan metode Bray 1, Cadd, KTK dengan metode ekstraksi
NH4OAc1N pH : 7 dan Hdd, Aldd dengan metode ekstraksi $\mathrm{KCl} 1 \mathrm{~N}$. Pengamatan dilakukan dengan menganalisa sampel tanah sebelum perlakuan dan setelah inkubasi di Laboratorium Kimia dan Kesuburan Tanah Fakultas Pertanian Universitas Tanjungpura.

Untuk analisis data menggunakan analisis keragaman (ANOVA), bila terdapat perbedaan nyata diantara perlakuan atau kombinasinya diteruskan uji beda jarak nyata Duncan (DMRT) pada taraf $5 \%$.

\section{HASIL DAN PEMBAHASAN}

Hasil analisis ragam menunjukkan bahwa faktor biochar sekam padi dan tepung cangkang kerang serta interaksi keduanya berpengaruh nyata terhadap perubahan komponen sifat kimia tanah ( $\mathrm{pH}$ tanah, Cadd, KTK, Aldd dan Hdd). Sementara itu interaksi perlakuan biochar sekam padi dan tepung cangkang kerang berpengaruh tidak nyata untuk komponen kimia $\mathrm{C}$ organik dan $\mathrm{P}_{2} \mathrm{O}_{5}$.

Data pada Tabel 1 menunjukkan untuk parameter $\mathrm{pH}$ tanah perlakuan $\mathrm{s}_{2} \mathrm{k}_{2}$ berbeda nyata dengan perlakuan $\mathrm{s}_{0} \mathrm{k}_{0}$, $\mathrm{s}_{0} \mathrm{k}_{1}, \mathrm{~s}_{0} \mathrm{k}_{2}, \mathrm{~s}_{1} \mathrm{k}_{0}, \mathrm{~s}_{1} \mathrm{k}_{1}, \mathrm{~s}_{1} \mathrm{k}_{2}, \mathrm{~s}_{2} \mathrm{k}_{0}$ dan $\mathrm{k}_{2} \mathrm{k}_{1}$. Hasil perhitungan rerata nilai $\mathrm{pH}$ menunjukan nilai rerata $\mathrm{pH}$ tertinggi pada perlakuan $\mathrm{s}_{2} \mathrm{k}_{2}$ yaitu sebesar 5,83 sementara untuk nilai rerata $\mathrm{pH}$ terendah terdapat pada perlakuan $\mathrm{s}_{0} \mathrm{k}_{0}$ yaitu sebesar 4,28 .

Tabel 1. Pengaruh interaksi biochar sekam padi dan tepung cangkang kerang terhadap $\mathrm{pH}$ tanah sulfat masam.

\begin{tabular}{lccc}
\hline Perlakuan & $\mathrm{s}_{0}$ & $\mathrm{~s}_{1}$ & $\mathrm{~S}_{2}$ \\
\hline $\mathrm{k}_{0}$ & $4,28 \mathrm{~g}$ & $4,64 \mathrm{f}$ & $5,26 \mathrm{c}$ \\
$\mathrm{k}_{1}$ & $4,76 \mathrm{e}$ & $5,07 \mathrm{~d}$ & $5,55 \mathrm{~b}$ \\
$\mathrm{k}_{2}$ & $5,33 \mathrm{c}$ & $5,56 \mathrm{~b}$ & $5,83 \mathrm{a}$ \\
\hline
\end{tabular}

Keterangan: Angka yang diikuti huruf yang sama tidak berbeda nyata berdasarkan uji Duncan Multiple Range Test (DMRT) $5 \%$.

Tabel 2. Pengaruh interaksi biochar sekam padi dan tepung cangkang kerang terhadap ketersediaan unsur Ca tanah sulfat masam.

\begin{tabular}{lccc}
\hline Perlakuan & $\mathrm{s}_{0}$ & $\mathrm{~s}_{1}$ & \\
\hline $\mathrm{k}_{0}$ & $1,26 \mathrm{e}$ & $0,53 \mathrm{f}$ & $0,62 \mathrm{f}$ \\
$\mathrm{k}_{1}$ & $1,31 \mathrm{e}$ & $1,50 \mathrm{e}$ & $1,97 \mathrm{~d}$ \\
$\mathrm{k}_{2}$ & $2,42 \mathrm{c}$ & $2,71 \mathrm{~b}$ & $3,00 \mathrm{a}$ \\
\hline
\end{tabular}

Keterangan: Angka yang diikuti huruf yang sama tidak berbeda nyata berdasarkan uji Duncan Multiple Range Test (DMRT) $5 \%$.

Tabel 3. Pengaruh interaksi biochar sekam padi dan tepung cangkang kerang terhadap KTK tanah sulfat masam.

\begin{tabular}{cccc}
\hline Perlakuan & $\mathrm{s}_{0}$ & $\mathrm{~s}_{1}$ & $\mathrm{~s}_{2}$ \\
\hline $\mathrm{k}_{0}$ & $22,67 \mathrm{a}$ & $17,45 \mathrm{c}$ & $19,89 \mathrm{~b}$ \\
$\mathrm{k}_{1}$ & $13,32 \mathrm{~d}$ & $18,22 \mathrm{c}$ & $21,61 \mathrm{a}$ \\
$\mathrm{k}_{2}$ & $13,58 \mathrm{~d}$ & $19,01 \mathrm{bc}$ & $22,55 \mathrm{a}$ \\
\hline
\end{tabular}

Keterangan: Angka yang diikuti huruf yang sama tidak berbeda nyata berdasarkan uji Duncan Multiple Range Test (DMRT) $5 \%$. 
Tabel 4. Pengaruh interaksi biochar sekam padi dan tepung cangkang kerang terhadap Aldd tanah sulfat masam.

\begin{tabular}{lccc}
\hline Perlakuan & $\mathrm{s}_{0}$ & $\mathrm{~s}_{1}$ & $\mathrm{~s}_{2}$ \\
\hline $\mathrm{k}_{0}$ & $0,16 \mathrm{a}$ & $0,12 \mathrm{~b}$ & $0,06 \mathrm{c}$ \\
$\mathrm{k}_{1}$ & $0,07 \mathrm{c}$ & $0,06 \mathrm{c}$ & $0,06 \mathrm{c}$ \\
$\mathrm{k}_{2}$ & $0,06 \mathrm{c}$ & $0,06 \mathrm{c}$ & $0,06 \mathrm{c}$ \\
\hline
\end{tabular}

Keterangan: Angka yang diikuti huruf yang sama tidak berbeda nyata berdasarkan uji Duncan Multiple Range Test (DMRT) $5 \%$.

Tabel 5. Pengaruh interaksi biochar sekam padi dan tepung cangkang kerang terhadap Hdd tanah sulfat masam.

\begin{tabular}{lccc}
\hline Perlakuan & $\mathrm{s}_{0}$ & $\mathrm{~s}_{1}$ & \\
\hline $\mathrm{k}_{0}$ & $0,68 \mathrm{a}$ & $0,35 \mathrm{~b}$ & $0,15 \mathrm{~cd}$ \\
$\mathrm{k}_{1}$ & $0,23 \mathrm{c}$ & $0,20 \mathrm{c}$ & $0,16 \mathrm{~cd}$ \\
$\mathrm{k}_{2}$ & $0,10 \mathrm{~d}$ & $0,17 \mathrm{~cd}$ & $0,20 \mathrm{c}$ \\
\hline
\end{tabular}

Keterangan : Angka yang diikuti huruf yang sama tidak berbeda nyata berdasarkan uji Duncan Multiple Range Test (DMRT) 5\%.

Tabel 6. Pengaruh tepung cangkang kerang terhadap komponen kimia tanah $\mathrm{C}$ organik dan $\mathrm{P}_{2} \mathrm{O}_{5}$.

\begin{tabular}{lccc}
\hline \multirow{2}{*}{ Parameter Analisis } & \multicolumn{3}{c}{ Tepung cangkang kerang } \\
\cline { 2 - 4 } & $\mathrm{k}_{0}$ & $\mathrm{k}_{1}$ & $\mathrm{k}_{2}$ \\
$\mathrm{C}$ Organik $\left(\mathrm{cmol}(+) \mathrm{kg}^{-1}\right)$ & $5,84 \mathrm{a}$ & $5,65 \mathrm{ab}$ & $5,49 \mathrm{~b}$ \\
$\mathrm{P}_{2} \mathrm{O}_{5}\left(\mathrm{cmol}(+) \mathrm{kg}^{-1}\right)$ & $46,64 \mathrm{a}$ & $41,76 \mathrm{a}$ & $40,56 \mathrm{a}$ \\
\hline
\end{tabular}

Keterangan: Angka yang diikuti huruf yang sama pada baris yang sama tidak berbeda nyata berdasarkan uji DMRT 5\%.

Tabel 7. Pengaruh biochar sekam padi terhadap komponen kimia Tanah $\mathrm{C}$ organik dan $\mathrm{P}_{2} \mathrm{O}_{5}$

\begin{tabular}{lcrc}
\hline \multirow{2}{*}{ Parameter Analisis } & \multicolumn{3}{c}{ Biochar sekam padi } \\
\cline { 2 - 4 }${\mathrm{C} \mathrm{Organik} \mathrm{cmol}(+) \mathrm{kg}^{-1}}^{2}$ & $\mathrm{~s}_{0}$ & $\mathrm{~s}_{1}$ & $5,48 \mathrm{~b}$ \\
$\mathrm{P}_{2} \mathrm{O}_{5} \mathrm{cmol}(+) \mathrm{kg}^{-1}$ & $5,66 \mathrm{ab}$ & $5,84 \mathrm{a}$ & $59,43 \mathrm{a}$ \\
\hline
\end{tabular}

Keterangan: Angka yang diikuti huruf yang sama pada baris yang sama tidak berbeda nyata berdasarkan uji DMRT 5\%.

Data pada Tabel 2 menunjukkan untuk parameter ketersedian unsur Ca perlakuan $\mathrm{s}_{2} \mathrm{k}_{2}$ berbeda nyata dengan perlakuan $\mathrm{s}_{0} \mathrm{k}_{0}, \mathrm{~s}_{0} \mathrm{k}_{1}, \mathrm{~s}_{0} \mathrm{k}_{2}, \mathrm{~s}_{1} \mathrm{k}_{0}, \mathrm{~s}_{1} \mathrm{k}_{1}, \mathrm{~s}_{1} \mathrm{k}_{2}, \mathrm{~s}_{2} \mathrm{k}_{0}$ dan $\mathrm{s}_{2} \mathrm{k}_{1}$. Hasil perhitungan rerata nilai ketersediaan unsur $\mathrm{Ca}$ menunjukkan bahwa nilai rerata ketersedian unsur $\mathrm{Ca}$ tertinggi pada perlakuan $\mathrm{s}_{2} \mathrm{k}_{2}$ yaitu sebesar $3,00 \mathrm{cmol}(+) \mathrm{kg}^{-1}$ sementara untuk nilai rerata ketersediaan unsur $\mathrm{Ca}$ terendah terdapat pada perlakuan $\mathrm{s}_{1} \mathrm{k}_{0}$ yaitu sebesar $0,53 \mathrm{cmol}(+) \mathrm{kg}^{-1}$.

Data pada Tabel 3 menunjukkan untuk parameter KTK perlakuan $\mathrm{s}_{0} \mathrm{k}_{0}$ berbeda nyata dengan perlakuan $\mathrm{s}_{1} \mathrm{k}_{0}$, $\mathrm{s}_{2} \mathrm{k}_{0}, \mathrm{~s}_{0} \mathrm{k}_{1}, \mathrm{~s}_{1} \mathrm{k}_{1}, \mathrm{~s}_{0} \mathrm{k}_{2}$ dan $\mathrm{s}_{1} \mathrm{k}_{2}$ namun tidak berbeda nyata dengan perlakuan $\mathrm{s}_{2} \mathrm{k}_{1}$ dan $\mathrm{s}_{2} \mathrm{k}_{2}$. Hasil perhitungan rerata nikai KTK menunjukkan bahwa nilai KTK tertinggi pada perlakuan $\mathrm{s}_{0} \mathrm{k}_{0}$ yaitu sebesar 22,66 $\mathrm{cmol}(+) \mathrm{kg}^{-1}$ sementara untuk nilai KTK terendah terdapat pada perlakuan $\mathrm{s}_{0} \mathrm{k}_{1}$ yaitu sebesar 13,32 $\mathrm{cmol}(+) \mathrm{kg}^{-1}$.

Data pada Tabel 4 menunjukkan untuk parameter Aldd perlakuan $\mathrm{s}_{0} \mathrm{k}_{0}$ berbeda nyata dengan perlakuan $\mathrm{s}_{0} \mathrm{k}_{1}$, $\mathrm{s}_{0} \mathrm{k}_{2}, \mathrm{~s}_{1} \mathrm{k}_{0}, \mathrm{~s}_{1} \mathrm{k}_{1}, \mathrm{~s}_{1} \mathrm{k}_{2}, \mathrm{~s}_{2} \mathrm{k}_{0}, \mathrm{~s}_{2} \mathrm{k}_{1}$ dan $\mathrm{s}_{2} \mathrm{k}_{2}$. Hasil perhitungan rerata nilai Aldd menunjukkan bahwa nilai Aldd tertinggi pada perlakuan $\mathrm{s}_{0} \mathrm{k}_{0}$ yaitu sebesar $0,16 \mathrm{cmol}(+) \mathrm{kg}^{-1}$ sementara untuk nilai Aldd terendah terdapat pada perlakuan $\mathrm{s}_{0} \mathrm{k}_{2}$ yaitu sebesar $0,06 \mathrm{cmol}(+) \mathrm{kg}^{-1}$ tidak berbeda nyata dengan perlakuan $\mathrm{s}_{0} \mathrm{k}_{1}, \mathrm{~s}_{1} \mathrm{k}_{1}, \mathrm{~s}_{1} \mathrm{k}_{2}, \mathrm{~s}_{2} \mathrm{k}_{0}, \mathrm{~s}_{2} \mathrm{k}_{1}$ dan $\mathrm{s}_{2} \mathrm{k}_{2}$.

Data pada Tabel 5 menunjukkan untuk parameter Hdd perlakuan $\mathrm{s}_{0} \mathrm{k}_{0}$ berbeda nyata dengan perlakuan $\mathrm{s}_{0} \mathrm{k}_{1}, \mathrm{~s}_{0} \mathrm{k}_{2}, \mathrm{~s}_{1} \mathrm{k}_{0}$ $\mathrm{s}_{1} \mathrm{k}_{1}, \mathrm{~s}_{1} \mathrm{k}_{2}, \mathrm{~s}_{2} \mathrm{k}_{0}, \mathrm{~s}_{2} \mathrm{k}_{1}$ dan $\mathrm{s}_{2} \mathrm{k}_{2}$. Hasil perhitungan rerata nilai Hdd menunjukkan bahwa nilai Hdd tertinggi pada perlakuan $\mathrm{s}_{0} \mathrm{k}_{0}$ yaitu sebesar $0,68 \mathrm{cmol}(+) \mathrm{kg}^{-1}$ sementara untuk nilai Hdd terendah terdapat pada perlakuan $\mathrm{s}_{0} \mathrm{k}_{2}$ yaitu sebesar 0,10 $\mathrm{cmol}(+) \mathrm{kg}^{-1}$ tidak berbeda nyata dengan perlakuan $\mathrm{s}_{1} \mathrm{k}_{2}, \mathrm{~s}_{2} \mathrm{k}_{0}$ dan $\mathrm{s}_{2} \mathrm{k}_{1}$.

Hasil analisis ragam menunjukkan tidak ada interaksi antar perlakuan dosis arang sekam dan dosis tepung cangkang pada komponen $\mathrm{C}$ organik dan $\mathrm{P}_{2} \mathrm{O}_{5}$. Hasil uji lanjut terhadap pengaruh perlakuan arang sekam dan tepung cangkang terhadap komponen $\mathrm{C}$ organik dan $\mathrm{P}_{2} \mathrm{O}_{5}$ dapat dilihat pada Tabel 6 dan Tabel 7.

Data Tabel 6 menunjukkan untuk parameter $\mathrm{C}$ organik perlakuan $\mathrm{K}_{0}$ berbeda nyata dengan perlakua $\mathrm{k}_{2}$, perlakuan $\mathrm{k}_{1}$ tidak berbeda nyata dengan perlakuan $\mathrm{k}_{0}$ dan $\mathrm{k}_{2}$. Hasil perhitungan rerata nilai $\mathrm{C}$ organik menunjukkan nilai rerata $\mathrm{C}$ 
organik tertinggi pada perlakuan $\mathrm{k}_{0}$ yaitu sebesar 5,84\% dan nilai rerata $\mathrm{C}$ organik terendah pada perlakuan $\mathrm{k}_{2}$ yaitu sebesar 5,49\%.

Untuk Parameter $\mathrm{P}_{2} \mathrm{O}_{5}$ perlakuan tepung cangkang tidak berbeda nyata untuk semua taraf perlakuan tepung cangkang.

Tabel 7 menunjukkan untuk parameter $\mathrm{C}$ organik perlakuan $\mathrm{s}_{1}$ berbeda nyata dengan perlakuan $\mathrm{s}_{2}$ namun tidak berbeda nyata dengan perlakuan $\mathrm{s}_{0}$. Nilai $\mathrm{C}$ organik tertinggi pada perlakuan $\mathrm{s}_{1}$ yaitu sebesar $5,84 \%$ dan nilai $\mathrm{C}$ organik terendah pada perlakuan $\mathrm{s}_{2}$ yaitu sebesar $5,48 \%$.

Untuk parameter $\mathrm{P}_{2} \mathrm{O}_{5}$ perlakuan arang sekam $\mathrm{s}_{2}$ berbeda nyata dengan perlakuan $\mathrm{s}_{0}$ dan $\mathrm{s}_{1}$. Perlakuan arang sekam $\mathrm{s}_{1}$ tidak berbeda nyata dengan perlakuan $\mathrm{s}_{0}$. Hasil perhitungan rerata nilai $\mathrm{P}_{2} \mathrm{O}_{5}$ menunjukkan nilai $\mathrm{P}_{2} \mathrm{O}_{5}$ tertinggi pada perlakuan $\mathrm{s}_{2}$ yaitu sebesar $59,43 \mathrm{cmol}(+) \mathrm{kg}^{-1}$ dan nilai $\mathrm{P}_{2} \mathrm{O}_{5}$ terendah pada perlakuan $\mathrm{s}_{0}$ yaitu sebesar 32,20 cmol(+) $\mathrm{kg}^{-1}$.

Pengaruh biochar sekam padi dan tepung cangkang kerang terhadap perubahan $\mathrm{pH}$ dan $\mathrm{Ca}$ tanah sulfat masam.

Data uji lanjut pengaruh biochar sekam padi dan tepung cangkang kerang terhadap parameter sifat kimia tanah menunjukkan bahwa kombinasi perlakuan biochar sekam padi dan tepung cangkang kerang berpengaruh nyata terhadap peningkatkan $\mathrm{pH}$ tanah. Hal ini terbukti dengan perlakuan biochar sekam padi dan tepung cangkang kerang $\mathrm{pH}$ tanah meningkat dari 4,3 menjadi 5,8 (Tabel 1). Hal ini disebabkan karena Cangkang Kerang Ale Ale mengandung unsur Ca dan $\mathrm{Mg}$. Dari hasil analisa tepung cangkang ale-ale mengandung $10,05 \% \mathrm{Ca}, 0,18 \% \mathrm{Mg}$ serta daya netralisasi sebesar $98,83 \%$, dimana kedua unsur ini dalam bentuk senyawa $\mathrm{CaO}$ dan $\mathrm{MgO}$ melalui reaksi hidrolisis dapat melepaskan ion $\mathrm{OH}^{-}$yang berpengaruh terhadap peningkatan $\mathrm{pH}$ tanah (Nyakpa, et al. .1988). Menurut Sumaryo dan Suryono (2000), pengapuran dapat menambah ketersediaan $\mathrm{Ca}$ dan $\mathrm{Mg}$ dalam tanah, sehingga dapat memacu turgor sel dan pembentukan klorofil yang menjadikan proses fotosintesis menjadi lebih meningkat. Pemberian biochar sekam padi dikatakan berpengaruh nyata dalam meningkatkan $\mathrm{pH}$ tanah sulfat masam. Hasil penelitian ini mendukung penelitian sebelumnya oleh (Purba 2015) menunjukkan bahwa bahan organik menghasilkan asam-asam organik yang mampu mengikat senyawa logam, sehingga dapat meningkatkan $\mathrm{pH}$ tanah.

\section{Pengaruh biochar sekam padi dan tepung cangkang kerang terhadap perubahan Aldd dan Hdd tanah sulfat masam.}

Selain meningkatkan $\mathrm{pH}$ tanah dan kandungan $\mathrm{Ca}$ yang bersumber dari pemberian biochar sekam padi dan kapur dari bahan tepung cangkang kerang juga menurunkan kandungan Aldd dan Hdd. Hasil penelitian ini mendukung penelitian sebelumnya oleh (Agusni, 2012) bahwa penambahan bahan organik pada tanah masam mampu meningkatkan $\mathrm{pH}$ tanah dan menurunkan $\mathrm{Al}$ tertukar (Al-dd), karena asam-asam organik hasil dekomposisi akan menghasilkan kation basa dan mengikat Al membentuk senyawa komplek, sehingga Al tidak terhidrolisis lagi. Menurut Havlin, et al.,(2005), pemberian bahan amelioran yaitu kapur dapat mengurangi kemasaman tanah (pH meningkat) oleh perubahan beberapa $\mathrm{H}^{+}$menjadi air. Nilai $\mathrm{pH}$ di atas 5,5 $\mathrm{Al}$ akan mengendap sebagai $\mathrm{Al}(\mathrm{OH})_{3}$, sehingga akan menurunkan sifat racun $\mathrm{Al}^{3+}$ dan mengurangi sumber pembentukan $\mathrm{H}+$. Hal ini terbukti dengan menurunnya nilai Aldd dari 0,16 menjadi 0,06 dan nilai Hdd dari 0,68 menjadi 0,10 (Tabel 4 dan Tabel 5). Menurut Uguru et al. . (2012), kemasaman tanah yang tinggi menyebabkan tingginya kelarutan $\mathrm{Al}^{3+}$ yang bersifat toksik bagi tanaman. Aluminium berpengaruh terhadap proses pembelahan dan pemanjangan sel meristematik di akar, sehingga menghambat pertumbuhan akar dan mengurangi penyerapan air dan hara terutama $\mathrm{Ca}$, $\mathrm{Mg}$ dan $\mathrm{P}$ yang berperan dalam proses fisiologi dan biokimia tanaman. Pemberian tepung cangkang kerang dengan dosis 24,28 g/polybag dapat meningkatkan $\mathrm{pH}$ tanah menjadi 5,57 dan menurunkan kelarutan $\mathrm{Al}^{3+}$ menjadi 0,06 (Tabel 4). Hal ini sesuai dengan pernyataan Hakim et al. (1986), pengaruh tidak langsung dari pengapuran adalah perbaikan ciri-ciri kimia tanah seperti: $\mathrm{pH}, \mathrm{Ca}$, dan unsur hara lainya yang meningkat. Al-dd dan kejenuhan Al yang berkurang, akibat penambahan kapur menciptakan suasana tumbuh yang baik bagi akar (Hakim et al. ., 1986). Pengaruh yang sama ditunjukan pada perlakuan biochar sekam padi dosis $10 \%$ dapat meningkatkan $\mathrm{pH}$ tanah menjadi 5,55 sehingga berdampak pada penurunan kelarutan $\mathrm{Al}^{3+}$ dalam tanah menjadi 0,06 (Tabel 4).

\section{Pengaruh biochar sekam padi dan tepung cangkang kerang terhadap perubahan C organik dan KTK tanah sulfat masam.}

Hasil analisis ragam menunjukkan perlakuan dosis biochar sekam padi secara tunggal tidak memberikan pengaruh nyata terhadap peningkatan kandungan $\mathrm{C}$ organik tanah. Namun perlakuan biochar sekam padi dengan dosis $5 \%\left(\mathrm{~s}_{1}\right)$ dapat meningkatan $\mathrm{C}$ organik tanah dibandingkan perlakuan tanpa biochar sekam padi $\left(\mathrm{s}_{0}\right)$ yaitu dari $5,66 \%$ menjadi 5,84\%. Hal ini diduga karena kandungan $\mathrm{C}$ organik awal tanah sulfat masam termasuk dalam kategori sangat tinggi yaitu 6,26\% (Pusat Penelitian Tanah, 1983). Sehingga penambahan biochar kedalam tanah sulfat masam tidak berpengaruh signifikan.

Hasil uji lanjut untuk parameter KTK menunjukkan bahwa perlakuan pemberian biochar sekam padi dan tepung cangkang kerang menunjukan penurunan nilai KTK tanah sulfat masam. Pada perlakuan kontrol $\left(\mathrm{s}_{0} \mathrm{k}_{0}\right)$ nilai KTK sebesar 22,66 cmol(+) $\mathrm{kg}^{-1}$. Nilai KTK tersebut sesuai dengan kriteria penilaian sifat kimia tanah menurut (Pusat Penelitian Tanah, 1983) tergolong sedang $17-24 \operatorname{cmol}(+) \mathrm{kg}^{-1}$. Kemudian setelah perlakuan pemberian biochar sekam padi terjadi penurunan nilai KTK. Pemberian biochar sekam padi tidak berpengaruh signifikan dalam meningkatkan nilai KTK tanah sulfat masam dikarenakan nilai KTK tersebut sebelum diberi biochar sudah dalam kategori nilai KTK yang sedang. Menurut Suastika (2010), nilai KTK tanah sulfat masam 
tergolong tinggi sampai sangat tinggi yaitu 31,50 - 62,50 cmol(+) $\mathrm{kg}^{-1}$ tanah di lapisan atas, dan tinggi yaitu 28,90 $32,70 \mathrm{cmol}(+) \mathrm{kg}^{-1}$ tanah dilapisan bawah karena pengaruh kandungan bahan organik yang sangat tinggi. Sehingga pada pemberian dosis biochar sekam padi terjadi penurunan nilai KTK tetapi tidak signifikan terhadap dosis kontrol.

Sementara penambahan Tepung cangkang kerang tidak memberikan pengaruh terhadap kenaikan KTK hal ini disebabkan karena pemberian cangkang kerang didominasi kandungan kalsium, karbonat dan tidak ada bahan lain untuk penambahan clay yang baru seperti humus atau bahan mineral yang mempunyai sifat koloid, sehingga tidak mempengaruhi nilai KTK tanah. Pada tanah-tanah bermuatan tergantung $\mathrm{pH}$, seperti tanah kaya koloid organik, maka KTK akan meningkat seiring dengan kenaikan $\mathrm{pH}$ akibat pengapuran. Dengan demikian dikatakan bahwa pengaruh pemberian kapur akan berkaitan erat dengan perubahan $\mathrm{pH}$, yang selanjutnya mempengaruhi KTK tanah (Soepardi 1983).

Pengaruh biochar sekam padi dan tepung cangkang kerang terhadap perubahan Senyawa $\mathrm{P}_{2} \mathrm{O}_{5}$ tanah sulfat masam.

Data Tabel 7 menujukkan perlakuan biochar sekam padi $10 \%$ dapat meningkatkan jumlah senyawa $\mathrm{P}_{2} \mathrm{O}_{5}$ dalam tanah dari 32,198 ppm menjadi 59,426 ppm atau bertambah sebanyak 53\% dari kandungan tanah awal. Pemberian bahan organik dapat menurunkan adsopsi $\mathrm{P}$ karena dekomposisi bahan organik menghasilkan asam asam organik yang dapat menyelimuti permukaan liat (Akande et al. 2010). Berbeda dengan bahan organik lainnya di dalam tanah biochar menjerap unsur hara $\mathrm{P}$ lebih kuat (Cheng et al. 2006). P dapat dilepas melalui organo kompleks pada ujung -ujung aromatik biochar sekam padi pada gugus fungsional dari asam organik, keadaan tersebut menyebabkan luas permukaan adsorpsi $\mathrm{P}$ berkurang, dengan menurunnya adsorpsi $\mathrm{P}$ tanah meningkatkan ketersediaan P. Menurut Hardjoloekito (2009), unsur fosfor sangat diperlukan untuk pembentukan atau pertumbuhan generatif tanaman. Terpenuhinya kebutuhan hara $\mathrm{P}$ akan meningkatkan aktivitas metabolisme sehingga bahan organik yang ditranslokasikan ke biji atau polong juga meningkat. Sesuai dengan pendapat Hidayat (2008), bertambahnya suplai fosfor dalam tubuh tanaman akan meningkatkan metabolisme sehingga proses pengisian biji optimal dan berat biji meningkat.

\section{KESIMPULAN}

Berdasarkan penelitian yang telah dilaksanakan menunjukan bahwa hasil terbaik untuk memperbaiki sifat kimia tanah sulfat masam adalah perlakuan biochar sekam padi dengan dosis $1200 \mathrm{~g} /$ polybag dan tepung cangkang kerang ale ale dengan dosis 24,28 g/polybag.

\section{DAFTAR PUSTAKA}

Akande, M. O., Makinde, E. A., Oluwatoyinbo, F. I., \& Adetunji, M. T. (2010). Effects of phosphate rock application on dry matter yield and phosphorus recovery of maize and cowpea grown in sequence. African Journal of Environmental Science and Technology, 4(5).

Asikin-Mijan, N., Taufiq-Yap, Y. H., \& Lee, H. V. (2015). Synthesis of clamshell derived $\mathrm{Ca}(\mathrm{OH}) 2$ nanoparticles via simple surfactant-hydration treatment. Chemical Engineering Journal, 262, 10431051.

Cheng, C. H., Lehmann, J., Thies, J. E., Burton, S. D., \& Engelhard, M. H. (2006). Oxidation of black carbon by biotic and abiotic processes. Organic geochemistry, 37(11), 1477-1488.

Hakim, N., M.Y. Nyakpa, A.M. Lubis, S.G. Nugroho, M.R. Saul, M.A. Diha, G.B. Hong, \& H.H. Bayley. (1986). Dasar-Dasar Ilmu Tanah. Universitas Lampung, Lampung.

Hardjoloekito, A. J. H. (2009). Pengaruh pengapuran dan pemupukan $\mathrm{P}$ terhadap pertumbuhan dan hasil tanaman kedelai (Glycine max L.) pada tanah latosol. Jurnal Media Soerjo, 5(2), 1-19.

Havlin, J. L., Beaton, J. D., Nelson, S. L., \& Nelson, W. L. (2005). Soil Fertility and Fertilizer, An Introduction to Nutrient Management 528 p. Pearson Prentice. Hall. New Jersey.

Hidayat, N. (2008). Pertumbuhan dan produksi kacang tanah (Arachis hypogea L.) varietas lokal Madura pada berbagai jarak tanam dan dosis pupuk fosfor. Agrovigor: Jurnal Agroekoteknologi, 1(1), 5564.

Nyakpa. M. Y, A.M . Lubis, M.A. Pulung, A.G. Amran, A. Munawar, G.B. Hong dan N. Hakim. (1988). Kesuburan Tanah. Universitas Lampung.

Priatmadi, B. J., \& Haris, A. (2009). Reaksi pemasaman senyawa pirit pada tanah rawa pasang surut. Journal of Tropical Soils, 14(1), 19-24.

Purba, M. A., Fauzi, F., \& Sari, K. (2015). Pengaruh Pemberian Fosfat Alam dan Bahan Organik pada Tanah Sulfat Masam Potensial Terhadap P-Tersedia Tanah dan Produksi Padi (Oryza sativa L.). Jurnal Agroekoteknologi Universitas Sumatera Utara, 3(3), 105094.

Purnomo, E., Mursyid, A., Syarwani, M., Jumberi, A., Hashidoko, Y., Hasegawa, T., ... \& Osaki, M. (2005). Phosphorus solubilizing microorganisms in the rhizosphere of local rice varieties grown without fertilizer on acid sulfate soils. Soil Science \& Plant Nutrition, 51(5), 679-681. 
Satriawan, H. (2012). Perubahan kualitas tanah ultisol akibat penambahan berbagai sumber bahan organik. Lentera: Jurnal Ilmiah Sains dan Teknologi, 12(3), 146473.

Soepardi, G. (1983). Sifat dan Ciri Tanah. Departemen Ilmu Tanah. Fakultas Pertanian. Institut Pertanian Bogor. Bogor.

Suastika, I. W., Hartatik, W., \& Subiksa, I. G. M. (2006). Karakteristik dan teknologi pengelolaan lahan sulfat masam mendukung pertanian ramah lingkungan.

Suhardjo, H., Soepraptohardjo, M., Subagyo, I., Marsoedi, D. S., Hidayat, A., \& Dai, Y. (1981). Jenis dan Macam
Tanah di Indonesia untuk Keperluan Survei dan Pemetaan Tanah Daerah Transmigrasi. P3MT, Pusat Penelitian Tanah. Publ, (28).

Sumaryo, S. (2000). Pengaruh dosis pupuk dolomit dan SP36 terhadap jumlah bintil akar dan hasil tanaman kacang tanah di tanah latosol. J. Agrosaitn, 2(2).

Uguru, M. I., Oyiga, B. C., \& Jandong, E. A. (2012). Responses of some soybean genotypes to different soil $\mathrm{pH}$ regimes in two planting seasons. The African Journal of Plant Science and Biotechnology, 6(1), 2637. 